\title{
Association between outdoor ozone and compensated acute respiratory diseases among workers in Quebec (Canada)
}

\author{
Ariane ADAM-POUPART ${ }^{1}$, France LABRÈCHE ${ }^{1,2}$, Marc-Antoine BUSQUE ${ }^{2}$, Allan BRAND $^{3}$, \\ Patrice DUGUAY ${ }^{2}$, Michel FOURNIER ${ }^{4}$, Joseph ZAYED ${ }^{1,2}$ and Audrey SMARGIASSI ${ }^{1,3 *}$ \\ ${ }^{1}$ Department of Environmental and Occupational Health, School of Public Health, Université de Montréal, \\ Canada \\ ${ }^{2}$ Institut de Recherche Robert-Sauvé en Santé et Sécurité du Travail (IRSST), Canada \\ ${ }^{3}$ Institut National de Santé Publique du Québec (INSPQ), Canada \\ ${ }^{4}$ Direction de Santé Publique, Agence de la Santé et des Services Sociaux de Montréal, Canada
}

Received July 4, 2014 and accepted December 8, 2014

Published online in J-STAGE January 10, 2015

\begin{abstract}
Respiratory effects of ozone in the workplace have not been extensively studied. Our aim was to explore the relationship between daily average ozone levels and compensated acute respiratory problems among workers in Quebec between 2003 and 2010 using a time-stratified casecrossover design. Health data came from the Workers' Compensation Board. Daily concentrations of ozone were estimated using a spatiotemporal model. Conditional logistic regressions, with and without adjustment for temperature, were used to estimate odds ratios (ORs, per $1 \mathrm{ppb}$ increase of ozone), and lag effects were assessed. Relationships with respiratory compensations in all industrial sectors were essentially null. Positive non-statistically significant associations were observed for outdoor sectors, and decreased after controlling for temperature (ORs of $0.98 ; 1.01$ and 1.05 at Lags 0,1 and 2 respectively). Considering the predicted increase of air pollutant concentrations in the context of climate change, closer investigation should be carried out on outdoor workers.
\end{abstract}

Key words: Air pollution, Compensation data, Ozone, Respiratory diseases, Workers

Ozone is a major air pollutant responsible for acute and chronic damages to the respiratory system ${ }^{1)}$, and there is increasing evidence suggesting that outdoor workers are at risk of ozone-related respiratory effects ${ }^{2}$. In the context of climate change, predicted increases in surface temperature and greenhouse gases emissions could result in the increase of background surface ozone ${ }^{3)}$. Workers could be exposed to higher concentrations of this pollutant in the future, especially on warm days when ozone levels are known to

*To whom correspondence should be addressed.

E-mail: audrey.smargiassi@umontreal.ca

(C)2015 National Institute of Occupational Safety and Health be high ${ }^{4}$. Our aim was to explore the relationship between daily average ozone levels and compensated acute respiratory diseases among workers in Quebec (Canada).

Compensation data came from the Workers' Compensation Board (WCB) of Quebec, the exclusive provider of compensations for employment injuries and illnesses for persons who do remunerated work for an employer in Quebec. The period of study was from May 1st to September 30th of each year between 2003 and 2010. These months cover the period when outdoor ozone levels are higher, as concentrations during the winter are almost null in Quebec ${ }^{5)}$, while the years of study were chosen according to availability of data. In the WCB database, all 
injuries coded for Respiratory system diseases according to the Canadian Standards Association (Standard Z795) were retained, except those resulting from stings of wasps, bees and hornets, and from the ingestion of substances. No claim was compensated more than once for the same illness within $31 \mathrm{~d}$.

The study area was restricted to the territory where daily ozone levels were available (Fig. 1). Daily average levels of ozone (9-17 h) were obtained from a Bayesian Maximum Entropy spatiotemporal model, developed over Quebec $\left(\mathrm{R}^{2}=0.653\right.$; Root mean square error $\left.=7.06 \mathrm{ppb}\right)$. Details on the model can be found in Adam-Poupart et $a l^{5}$.

We assessed the relation between daily ozone levels and compensated acute respiratory problems using a case-crossover design ${ }^{6}$. In this design, temporal trends are adjusted for by selecting control days for each day in which at least one acute respiratory problem occurred (case day). This design partially controls for potential confounders by making within-subject (i.e. workers) comparisons. Using a time-stratified approach in which the study period is divided into monthly strata, we selected as control days for each case day the same days of the other weeks in the same month. Thus, if a respiratory problem occurred on Tuesday 10 March 2009, the selected control days were other Tuesdays of the same month (3, 17, 24 and 31 March 2009). Daily mean ozone concentrations were estimated for the six-digit postal code of each employer establishment's location on case and control days.

Conditional logistic regressions were used to compare daily mean ozone levels for case days with their matched control days. Case days with less than three control days were discarded. Odds ratios (ORs) and their $95 \%$ confidence intervals (CIs) were expressed per 1 ppb increase of ozone levels. Models were adjusted for daily mean temperature (9-17 h), estimated from hourly meteorological data available from the Environment Canada Data Access Integration Team (http://loki.qc.ec.gc.ca/DAI/DAI-e.html). Additionally, the statistical interaction between ozone and temperature was verified by adding a product term to the model.

Analyses were conducted for all industrial sectors and then restricted to industries with mostly outside work (i.e. agriculture, construction, fishing/hunting/trapping, forestry/logging/supporting activities, mining/quarrying/oil/ gas extraction, and transport/warehousing). We assessed possible time-lag effects by looking at the association between compensations and ozone levels of the current day (lag 0 ), and of the two previous days (lag 1 and lag 2). The cumulative effect of two-day (mean of lags $0-1$ ) and threeday (mean of lags $0-1-2$ ) moving averages of daily levels

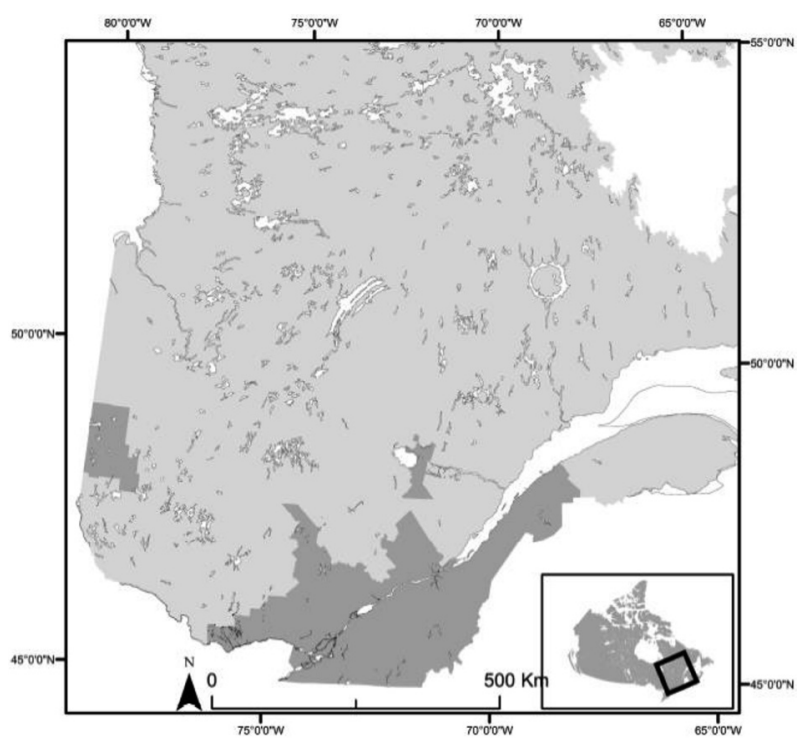

Fig. 1. Geographical location the territory (dark grey) where daily ozone levels were available in Quebec (Canada).

of ozone was also estimated. All analyses were conducted with Stata version 12.1.

Overall, 328 respiratory diseases were compensated in Quebec from 2003 to 2010 (May-Sept). Of these compensations, 252 were retained for analysis, as they occurred in areas for which we could estimate ozone concentrations on case and control days. Only 26 compensations occurred in industrial sectors with mostly outdoor work. The number of compensations per type of acute respiratory problem and industrial sector is presented in Table 1. Estimates of daily average concentrations of ozone on case days retained for the analysis ranged from 9.2 to $59.8 \mathrm{ppb}$ (mean of $28.1 \mathrm{ppb}$ ) and daily mean temperature from 5.3 to $30.5^{\circ} \mathrm{C}$ (mean of $19.2^{\circ} \mathrm{C}$ ). Estimates of daily average concentrations of ozone on control days ranged from 6.9 to $61.4 \mathrm{ppb}$ (mean of $28.0 \mathrm{ppb}$ ) and daily mean temperature from 2.9 to $31.8^{\circ} \mathrm{C}$ (mean of $19.2{ }^{\circ} \mathrm{C}$ ).

Associations between ozone estimates and compensated acute respiratory problems are detailed in Table 2. Crude relationships with respiratory compensations in all industrial sectors were essentially null, the adjustment for temperature increased the effect of ozone and the interactions between daily ozone and daily mean temperature were significant at almost all lags and moving averages. In sectors with mostly outdoor work, crude associations for compensations were all positive (all lags and moving averages); however a large statistical variability was noted and adjusting for temperature reduced the effect of ozone. For these sectors, no statistical interaction was found between 
Table 1. Number of compensations per type of respiratory problems and industrial sectors (Quebec, May-September 2003-2010)

\begin{tabular}{|c|c|c|}
\hline & Number of compensations & $(\%)$ \\
\hline \multicolumn{3}{|l|}{ Natures } \\
\hline Extrinsic asthma & 70 & 27.8 \\
\hline Reactive airways dysfunction syndrome & 28 & 11.1 \\
\hline Acute respiratory infections & 25 & 9.9 \\
\hline Other respiratory system diseases. NEC ${ }^{a}$ & 23 & 9.1 \\
\hline Influenza & 15 & 6.0 \\
\hline Bronchitis & 13 & 5.2 \\
\hline Respiratory system diseases. UNS ${ }^{a}$ & 10 & 4.0 \\
\hline Pneumonia. influenza. NEC ${ }^{a}$ & 10 & 4.0 \\
\hline Chronic obstructive pulmonary diseases and allied conditions. NEC & 9 & 3.6 \\
\hline Pneumonitis. NEC ${ }^{a}$ & 8 & 3.2 \\
\hline Allergic rhinitis & 7 & 2.8 \\
\hline Pneumonia & 6 & 2.4 \\
\hline Chronic conditions of upper respiratory tract & 5 & 2.0 \\
\hline Diseases of upper respiratory tract. UNS ${ }^{\mathrm{a}}$ & 3 & 1.2 \\
\hline diseases of upper respiratory tract. $\mathrm{NEC}^{\mathrm{a}}$ & 3 & 1.2 \\
\hline Asbestosis & 3 & 1.2 \\
\hline Pulmonary edema & 3 & 1.9 \\
\hline Chronic obstructive pulmonary diseases and allied conditions. UNS ${ }^{\mathrm{a}}$ & 2 & 0.8 \\
\hline Chronic obstructive lung disease & 2 & 0.8 \\
\hline Pneumonia. influenza. UNS ${ }^{\mathrm{a}}$ & 1 & 0.4 \\
\hline Legionnaires' disease & 1 & 0.4 \\
\hline Extrinsic allergic alveolitis and pneumonitis Includes: farmers' lung. bagassosis & 1 & 0.4 \\
\hline Silicosis & 1 & 0.4 \\
\hline Berylliosis & 1 & 0.2 \\
\hline Byssinosis. mill fever & 1 & 0.4 \\
\hline Pneumonopathy. NEC ${ }^{a}$ & 1 & 0.4 \\
\hline Pulmonary fibrosis. NEC ${ }^{a}$ & 1 & 0.4 \\
\hline \multicolumn{3}{|l|}{ Industrial Sectors } \\
\hline Manufacturing & 78 & 31.0 \\
\hline Health care and social assistance & 62 & 24.6 \\
\hline Wholesale and Retail trade & 26 & 10.3 \\
\hline Construction & 11 & 4.4 \\
\hline Educational services & 11 & 4.4 \\
\hline Waste management and remediation services; Management of companies and enterprises; & 10 & 4.0 \\
\hline \multicolumn{3}{|l|}{ Administrative and support services } \\
\hline Unclassified & 10 & 4.0 \\
\hline Public administration & 8 & 3.2 \\
\hline Agriculture & 7 & 2.8 \\
\hline Transportation and warehousing & 7 & 2.8 \\
\hline Professional. scientific and technical services & 5 & 2.0 \\
\hline Accommodation and food services & 5 & 2.0 \\
\hline Other services including Repair and maintenance (except public administration) & 4 & 1.6 \\
\hline Finance and insurance & 3 & 1.2 \\
\hline Utilities & 2 & 0.8 \\
\hline Information and cultural industries; Arts. entertainment and recreation & 2 & 0.8 \\
\hline Mining. quarrying. oil and gas extraction & 1 & 0.4 \\
\hline Forestry. logging and supporting activities & 0 & 0.0 \\
\hline Fishing. hunting and trapping & 0 & 0.0 \\
\hline
\end{tabular}

${ }^{a} U N S$ : Unspecified; NEC; Not elsewhere classified 
Table 2. Associations between ozone estimates and compensated acute respiratory problems among workers, for each 1 ppb increment of average ozone levels, in Quebec, May-September 2003-2010

\begin{tabular}{|c|c|c|c|c|c|c|c|c|}
\hline \multirow{3}{*}{$\begin{array}{l}\text { Timing of } \\
\text { ozone } \\
\text { exposure }\end{array}$} & \multicolumn{4}{|c|}{ All compensations (2003-2010) } & \multicolumn{4}{|c|}{ Compensations for sectors with mostly outdoor work $(2003-2010)^{b}$} \\
\hline & \multirow[t]{2}{*}{$\begin{array}{c}\text { Days with } \\
\text { compensations (n) }\end{array}$} & \multicolumn{2}{|c|}{$\begin{array}{l}\text { OR per } 1 \text { ppb increase } \\
\text { in daily average ozone } \\
\text { concentration }(95 \% \mathrm{CI})\end{array}$} & \multirow{2}{*}{$\begin{array}{c}\begin{array}{c}\text { Interaction } \\
\text { between ozone } \\
\text { and temperature }\end{array} \\
p \text { value }\end{array}$} & \multirow[t]{2}{*}{$\begin{array}{c}\text { Days with } \\
\text { compensations (n) }\end{array}$} & \multicolumn{2}{|c|}{$\begin{array}{l}\text { OR per } 1 \mathrm{ppb} \text { increase } \\
\text { in daily average ozone } \\
\text { concentration }(95 \% \mathrm{CI})\end{array}$} & \multirow{2}{*}{$\begin{array}{c}\text { Interaction } \\
\text { between ozone } \\
\text { and temperature } \\
p \text { value }\end{array}$} \\
\hline & & Not adjusted & Adjusted $^{\mathrm{c}}$ & & & Not adjusted & Adjusted $^{\mathrm{c}}$ & \\
\hline Lag 0 & 252 & $\begin{array}{c}1.01 \\
(0.98 ; 1.03) \\
\end{array}$ & $\begin{array}{c}1.01 \\
(0.98 ; 1.05) \\
\end{array}$ & $<0.01$ & 26 & $\begin{array}{c}1.02 \\
(0.95 ; 1.10) \\
\end{array}$ & $\begin{array}{c}0.98 \\
(0.88 ; 1.09) \\
\end{array}$ & 0.75 \\
\hline Lag 1 & 250 & $\begin{array}{c}1.00 \\
(0.97 ; 1.02) \\
\end{array}$ & $\begin{array}{c}1.01 \\
(0.98 ; 1.05) \\
\end{array}$ & 0.05 & 26 & $\begin{array}{c}1.04 \\
(0.96 ; 1.12) \\
\end{array}$ & $\begin{array}{c}1.01 \\
(0.91 ; 1.12) \\
\end{array}$ & 0.73 \\
\hline Lag 2 & 243 & $\begin{array}{c}1.00 \\
(0.97 ; 1.03) \\
\end{array}$ & $\begin{array}{c}1.01 \\
(0.98 ; 1.05) \\
\end{array}$ & 0.40 & 23 & $\begin{array}{c}1.06 \\
(0.98 ; 1.13) \\
\end{array}$ & $\begin{array}{c}1.05 \\
(0.93 ; 1.18) \\
\end{array}$ & 0.66 \\
\hline Lags $0-1^{\mathrm{d}}$ & 244 & $\begin{array}{c}1.00 \\
(0.98 ; 1.03) \\
\end{array}$ & $\begin{array}{c}1.01 \\
(0.98 ; 1.05) \\
\end{array}$ & $<0.01$ & 25 & $\begin{array}{c}1.03 \\
(0.95 ; 1.12) \\
\end{array}$ & $\begin{array}{c}0.98 \\
(0.87 ; 1.10) \\
\end{array}$ & 0.70 \\
\hline Lags $0-2^{\mathrm{e}}$ & 230 & $\begin{array}{c}1.00 \\
(0.97 ; 1.03)\end{array}$ & $\begin{array}{c}1.01 \\
(0.97 ; 1.06)\end{array}$ & 0.02 & 22 & $\begin{array}{c}1.05 \\
(0.95 ; 1.16)\end{array}$ & $\begin{array}{c}0.98 \\
(0.84 ; 1.15)\end{array}$ & 0.24 \\
\hline
\end{tabular}

${ }^{a}$ Compensations occurring in areas for which we could estimate ozone concentrations with the model on case and control days, and for which we had 3 or 4 control days per case day (106 case days out of 358 were excluded because they had less than 3 controls days). Missing ozone values on control days are spatiotemporal moment (postal code-days) that were not estimated with the BME model, due to lack of data. ${ }^{b}$ Sectors with mostly outdoor work: agriculture, construction, fishing/hunting/trapping, forestry/logging/supporting activities, mining/quarrying/oil and gas extraction, transport/warehousing. ${ }^{\mathrm{c}}$ Ajusted for mean daily temperature, evaluated on the same day as ozone estimates. ${ }^{\mathrm{d}}$ Two-day lag average. ${ }^{\mathrm{e}}$ Three-day lag average

ozone and temperature ( $p$-values varied from 0.24 to 0.75 ). An analysis was also performed after excluding the 28 cases of reactive airways dysfunction syndrome (RADS) as these often happen following accidental exposure to irritants, but the results were essentially unchanged (adjusted ORs for all industries varied across lags from 0.99 to 1.01 ; for sectors with mostly outdoor work, it varied from 0.93 to 1.02 ; data not presented).

The positive trend noted only for outdoor workers could be attributed to higher exposure of outdoor workers to ambient air pollution compared to indoor workers. Outdoor workers are classified as one of the most common categories of people at increased risk of ozone-related respiratory health effects due to the duration of exposure ${ }^{2}$. Moreover, some occupations in these sectors are physically demanding (i.e. roofers) and workers in these occupations could possibly inhale higher doses of pollutants because of the increase in minute ventilation associated with physical activity ${ }^{4}$. Delayed respiratory effect of ozone on outdoor workers, which was previously reported in mail carriers in Taiwan ${ }^{7)}$ and in berry pickers in Canada ${ }^{8,9)}$, is also suggested by the positive trend of associations from lag 0 to lag 2 noted for outdoor workers.

This study presents several limitations that could potentially explain the inconclusive results. Firstly, the statistical variability observed for the crude positive associations between ozone levels and respiratory compensations for outdoor workers may be explained, at least partially, by the small number of cases ( $\mathrm{n}=26$ case days). Secondly, we analyzed compensation data which is known to reflect only part of actual work-related injuries and illnesses ${ }^{10)}$. It is likely that our analysis underestimates the actual risks, as several industrial sectors with outdoor activities are well known for underreporting injuries, such as agriculture, forestry, fishing and construction ${ }^{11)}$. Between 2003 and 2010, 17 compensations occurred in these sectors compared to 26 for sectors with mostly outdoor work. Moreover, the lack of precision of both the health indicators and the exposure assessment methods could have resulted in the dilution of the ozone effect and be responsible for the inconclusive results. In the few studies where statistically significant associations between ozone and respiratory health effects were observed among workers, lung functions were evaluated more precisely using spirometry ${ }^{7-9,12)}$ or the exposure was assessed individually with portable sampling devices ${ }^{13)}$.

Lastly, the adjustment for temperature had varying influences on the effect of ozone; it barely influenced the magnitude of the association between ozone levels and respiratory compensations for all industrial sectors, but reduced the association for sectors with mostly outdoor work. Therefore, it is unclear if the observed trends for outdoor workers are due to ozone levels, to high temperatures or to other unmeasured parameters that are associated with them. 
Moreover, the statistical interaction between daily ozone and daily mean temperature was erratic. In the literature, the respiratory effect of a co-exposure to heat and ozone has never been explored in the workplace and conclusions on the role of ozone in health studies of heat exposure in the general population are inconsistent ${ }^{14)}$. In a recent review of the scientific epidemiological evidences on the respiratory effects of climate events (such as heat) combined to air quality (such as ozone) in the context of climate change, De Sario et al. ${ }^{15)}$ reported that the temperatureair pollution interactions can not be easily considered in temperature or air pollution respiratory studies, because the true magnitude of the association may be underrestimated.

However, several studies provided consistent evidence of a synergy between ozone and heat exposure, and from a toxicological perspective, interactions could occur during co-exposure: heat triggers a series of compensatory physiological responses, such as respiratory rate increases, which could simultaneously increase the volume of inhaled air and the ozone dose reaching the respiratory system $^{15)}$.

In conclusion, although the present study needs replication, its results nonetheless suggest a possible association between exposure to ozone and delayed acute respiratory problems among outdoor workers in Quebec and present some evidence of an interaction between ozone concentrations and temperature. Considering the predicted increase of ozone concentrations in the context of climate change ${ }^{3)}$, closer investigation should be carried out on the potential respiratory impact of this pollutant among outdoor workers. The co-exposure with other air pollutants that may have acute respiratory effects, such as fine particulates and nitrogen oxides ${ }^{7,13)}$ should also be assessed.

\section{Acknowledgements}

This work was funded by the Institut de Recherche Robert-Sauvé en Santé et en Sécurité du Travail (Grant number 2011-0047). A Adam-Poupart acknowledges the receipt of a scholarship from the Fonds de Recherche du Québec-Santé (FRQ-S).

\section{References}

1) Seguin J (2008) Human Health in a Changing Climate: A Canadian Assessment of Vulnerabilities and Adaptative Capacity. 546, Health Canada, Ottawa (Canada).

2) Vinikoor-Imler LC, Owens EO, Nichols JL, Ross M, Brown JS, Sacks JD, Sacks JD (2014) Evaluating potential responsemodifying factors for associations between ozone and health outcomes: a weight-of-evidence approach. Environ Health Perspect 122, 1166-76 [Epub ahead of print]. [Medline]

3) Intergovernmental Panel on Climate Change (IPCC) (2013) Summary for Policymakers. In: Climate Change 2013: The Physical Science Basis. Contribution of Working Group I to the Fifth Assessment Report of the Intergovernmental Panel on Climate Change Stocker TF, Qin D, Plattner G-K, Tignor M, Allen SK, Boschung J, Nauels A, Xia Y, Bex $\mathrm{V}$ and Midgley PM (Eds.)., Cambridge University Press, Cambridge and New York.

4) U.S. EPA (2013) Integrated science assessment for ozone and related photochemical oxidants. EPA/600/R-10/076F. Research Triangle Park, NC http://cfpub.epa.gov/ncea/isa/ recordisplay.cfm?deid=247492. Accessed June 24, 2014.

5) Adam-Poupart A, Brand A, Fournier M, Jerrett M, Smargiassi A (2014) Spatiotemporal modeling of ozone levels in Quebec (Canada): a comparison of kriging, landuse regression (LUR), and combined Bayesian maximum entropy-LUR approaches. Environ Health Perspect 122, 970-6. [Medline]

6) Maclure M (1991) The case-crossover design: a method for studying transient effects on the risk of acute events. Am J Epidemiol 133, 144-53. [Medline]

7) Chan CC, Wu TH (2005) Effects of ambient ozone exposure on mail carriers' peak expiratory flow rates. Environ Health Perspect 113, 735-8. [Medline] [CrossRef]

8) Brauer M, Blair J, Vedal S (1996) Effect of ambient ozone exposure on lung function in farm workers. Am J Respir Crit Care Med 154, 981-7. [Medline] [CrossRef]

9) Brauer M, Brook JR (1997) Ozone personal exposures and health effects for selected groups residing in the Fraser Valley. Atmos Environ 31, 2113-21. [CrossRef]

10) Shannon HS, Lowe GS (2002) How many injured workers do not file claims for workers' compensation benefits? Am J Ind Med 42, 467-73. [Medline] [CrossRef]

11) Fan ZJ, Bonauto DK, Foley MP, Silverstein BA (2006) Underreporting of work-related injury or illness to workers' compensation: individual and industry factors. J Occup Environ Med 48, 914-22. [Medline] [CrossRef]

12) Thaller EI, Petronella SA, Hochman D, Howard S, Chhikara RS, Brooks EG (2008) Moderate increases in ambient PM2.5 and ozone are associated with lung function decreases in beach lifeguards. J Occup Environ Med 50, 202-11. [Medline] [CrossRef]

13) Karakatsani A, Kapitsimadis F, Pipikou M, Chalbot MC, Kavouras IG, Orphanidou D, Papiris S, Katsouyanni K (2010) Ambient air pollution and respiratory health effects in mail carriers. Environ Res 110, 278-85. [Medline] [CrossRef]

14) Reid CE, Snowden JM, Kontgis C, Tager IB (2012) The role of ambient ozone in epidemiologic studies of heat-related mortality. Environ Health Perspect 120, 1627-30. [Medline]

15) De Sario M, Katsouyanni K, Michelozzi P (2013) Climate change, extreme weather events, air pollution and respiratory health in Europe. Eur Respir J 42, 826-43. [Medline] [CrossRef] 